\title{
6
}

\section{Aspects of Narration}

Novel reviewers in America before the Civil War did not discuss the novel as a verbal construct. While they showed an awareness that novels were composed of words, they entered the field of the novel at a far higher level of its organization than the verbal base. The assumption that the phenomena named as plot, character, and the like were properly understood by studying the lexical and syntactic units of the text-in other words, by reducing it to elementary particles--did not yet exist. Although it is impossible to know what their response would have been to such a notion, my guess is that they would think (as certain holistic biologists do today) that intervening levels of organization made the reduction of the novel to its basic particles of doubtful value for explaining its highest functions. And the highest functionsthat is, the effects of the whole on the reader-were their concern. Mid-nineteenth-century novel reviewing also lacked many of the intermediate language-centered levels of hierarchy that constitute such an important part of present-day practical novel criticism in scholarly as well as mass-circulation journals. There was, for example, no talk of symbols, metaphors, or imagery. Narrator and point of view had only a dimly perceived verbal existence. Even style, which all reviewers discussed, was treated at some remove from specifically identified language features.

Reviewers did recognize, however, that a number of different kinds of language acts contributed to the narrative totality, and they had a vocabulary for discerning and commenting on these. The chief evaluative criterion was subordination of such elements to the organizing principle of plot. All narrative elements 
were contributions; if they became intrusive, if they dominated the work, then the work became less like a novel. A predominantly descriptive novel, for example, was too much like an essay; a mainly conversational novel too much like a drama; a chiefly reflective novel too much like a sermon or treatise-and so on. While, however, each aspect of narration was functional with respect to a whole organized as a plot, and the best novelist was one who mastered and employed all of them, particular novelists might show particular abilities. Hence consideration of these subsidiary or dependent narrative features permitted reviewers to make specific judgments and to create useful critical descriptions of individual works and authors.

This commentary on Eastford from Grabam's for April I 855 conveys a reviewer's conception of the narrative totality. The author "has endeavored to make his book a representation of the common aspects of New England life and character. . . . The interest of the volume depends in no small degree on the exhibition of the struggle, now going on in every New England village, between old and new fashioned opinions.... The hero and heroine have the same rigid truth to actual life which characterizes the other personages. . . . The style of the volume is pure, sweet, graceful, and vigorous, indicating a practiced hand in composition. It is equal to all the demands of description, narration, conversation, and discussion. . . . The power of description is quite noticeable." This is a novel because it has a plot, a struggle involving a hero and heroine. The interest of the plot is enhanced because it refers to a real-life state of affairs, and a secondary, subordinate interest is created by the depiction, in local color fashion, of "aspects of New England life and character." Narration itself divides into description, narration proper, conversation, and discussion; style is a different, overlapping category separable from yet active in all these narrative tasks.

Description, as anyone who reads or writes narrative theory knows, is at best a problematic concept. It is difficult to distinguish from narration, since in the novel everything must be described. Reviewers in nineteenth-century American journals spoke of description when the object of narration was static, and of narration proper when it was active. Of course there is a nottoo-fine line where this division blurs; and the most common narrational faults in novels-diffuseness and overminuteness- 
occurred whether the subject was an event or an existent. Diffuseness simply meant writing too much and therefore slowing the action or bringing it to a halt even when action was the subject of discourse. George Sand, according to the North American, "refines too much, and overdoes the work with a minuteness of detail, that spoils the effect" (July I 84I). The Literary World complained that "the fault of Margaret Percival, as a work of fiction claiming to be received in the literature of the language, is its minuteness, even to tediousness"; it noted in another case that "the minuteness with which the characters are sketched, and the fidelity in conversation which they possess, are apt to weary ordinary readers eager for development of plot" (March 6, I 847; February 9, I 850). It identified the chief fault of Warner's The Wide, Wide World as "diffuseness. She tells a story or describes a scene with a woman's indiscriminate minuteness"; and it found the same problem in her Queechy: it is "too diffuse to please the hypercritical stickler for strictly artistic construction" (December 28, I 850; May 8, I 852). "Diffuseness is the main fault of Miss Chesebro', as of many other lady writers," it announced (December 18,1852 ). "By putting 'too fine a point' on many of the incidents, the author provokes a feeling of impatience," a Tribune reviewer complained of Cummins's The Lamplighter (March 28 , I 854).

Reviewers liked to associate diffuseness with women writers, in accordance with the stereotype of women as generally less well organized and less able than men to keep an ultimate end in view. But they did not claim that only women writers had this fault. Even such a master of narration as Cooper might be diffuse. "One capital defect," the North American wrote in an early (July I 822) review of The Spy, "is that excessive minuteness which leaves nothing for the imagination to supply. The enumeration of little unimportant actions-mere necessary consequences-and full length descriptions of the exact tone, look, and gesture, with which something, or nothing, is uttered, the precise graduation of this or that emotion . . . are prodigious weakeners of style." A Grabam's review of Cooper's Afloat and Ashore noted that "at times his attention to minutiae is so close, that, although it does not fatigue, it is still calculated to irritate a reader who is clamorous for incident, and desirous of being borne onward quickly to the completion of the story" (October I 844). The concept of pacing 
was not named, but it is some sense of a proper pace for narration that controls the assessment of diffuseness.

Because narration itself, the chronicling of event, was so basic to the success of a novel, most reviewers took it for granted and wrote little about it, though they occasionally singled out a particularly powerful narrational ability. Cooper, despite occasional minuteness, was widely considered to have an unusual gift for narration though, interestingly, not for plotting: while overall his stories were not coherent, event by event they were fascinating. The North American in January I 838 noted that Cooper "has that skill in narration, the first requisite of a novelist, which, fastening the reader's attention on the issue of events immediately before him, will not allow him to observe any improbability in the plot, or incongruity in the character and actions of the agents. . . It must be owned, however, that the author abuses his power." A retrospective review in July 1850 in the same journal made the same assessment: "his strength consisted chiefly in his descriptive power and his skill as a narrator. Many of the scenes and incidents created an interest that was almost painful. . . The remainder of the story through which these fine sketches were distributed was generally a curious piece of patchwork." A Southern Literary Messenger reviewer wrote similarly of G. P. R. James: "he has the art of interesting you in his narrative. He has the genuine talent of the racounteur. This is a talent of the first necessity to the writer of fiction. . . . The peculiar gift, of which we speak, is not inventiveness, for which it might be taken, but rather something which manages, blends, conducts, and adroitly makes the most of, invention. It is indeed a talent to itself, and by itself . . . an absolute necessity to a greatly successful novelist" (September I 847).

A writer distinguished for his pacing was the popular Alexandre Dumas, whom the Southern Literary Messenger found "remarkable for the curt and rapid management of details, which leaves no feature of his picture wanting or blurred; and yet with all his particularity he is never tedious. He really consumes less space in his minute and full narratives than most authors consume in that style of general description which pretends to dash off scenes with a few bold strokes" (September i 847). Unlike Dumas, many writers attempting to avoid minuteness or diff useness produced narratives lacking in consecutiveness. Disraeli's 
novels "want that adroit linking and sequency which should be present everywhere to secure and conduct the attention" (Southern Literary Messenger, December I 847). The Matchmaker is so "abrupt . . . that justice to the authoress obliges us to conjecture that the work has been despoiled of its original proportions" (Literary World, March 9, I 850). "In reading his scenes we always seem to have a play before us," a Grabam's review commented on Reade's White Lies. "There is a rapid shifting of scene, without sufficient connection-for a novel" (December I 857).

\section{Description}

Although it is impossible to tell just where narration leaves off and description begins, the distinction did enable reviewers roughly to separate aspects of narrative designed directly to advance and develop the plot from aspects concerned rather to explain or decorate it. Minimal descriptiveness was artistically preferable to diffuseness, but no plot could be interesting if it lacked elaboration of events and characters; and a plot would not be coherent without narrated transitions and connectives. "The author should remember," the Southern Literary Messenger admonished Charles Reade, "that what is called autorial comment must in romances supply the place of scenery, dresses, and acting in the drama" (July i 855). The basic way of evaluating description was to consider whether it ultimately strengthened or dissipated the interest of the plot. When an author had a gift for description reviewers liked to point it out. Where description was overdone, they pointed that out too.

The reader's interest in Simms's Guy Rivers, according to Knickerbocker, is "kept down, it may be, by a little stateliness and minutiae of style and description in the first few pages" (August I 835). "One great fault of the author," it wrote on Simms again (November I 839), "is too much description. He does not leave enough to the imagination of the reader." And again: Simms winds "envelopes of dry bombastic description" around his scenes and characters (April i 846). One Peterson's review observed of Eugene Sue, "there is no author living who can surpass this man in force and brilliancy of description" (July I 845); another attacked Reade's It Is Never Too Late to Learn for "tedious 
prolixity" (December I 856). Grabam's found "too much of quietly elaborated still life" in Marmaduke Wyvil (July I 843). "Historical and pictorial details" in Child's Philothea "are managed with much grace and adroitness, so that we are not wearied," a Tribune reviewer approved (June 3, I 845). Harper's noted that the subject of Agnes Sorel, by G. P. R. James, "affords an admirable opportunity for the exercise of the descriptive powers for which the author is remarkable" (April I 853). The Christian Examiner found Kingsley excelling "in description more than in dialogue or in narrative" (May i 857). Putnam's commented that Simms's works "have an undeniable tendency to prosiness, and the interest of description in them, which necessarily soon tires, is superior to that of characterization" (March I 857). Reviewers assumed that readers were interested in description only to a limited degree; "interest" remains supreme, and the safest authorial practice is to link all description firmly to the story.

Landscape description occupied a special place. Partly because of some persistence, especially in the earlier years of the period, of the eighteenth-century notion of the sublime, partly because Scott devoted space to scenic description, and partly because literary nationalism in America was associated with landscape, set pieces of landscape description appeared frequently, especially in American novels. Reviewers expected them, noted them, and assessed them as they did description more generally, for adding to or detracting from the progress of the narrative.

The North American (April I 825) approved the scenic descriptions in Sedgwick's Redwood while clarif ying the rules by which it was judging: "there is much beautiful and striking description, but it is never so drawn out as to be tiresome, nor introduced so as to interrupt the interest of the story." It generalized about American novels in January 1853 that "the new circumstances of our position, and the feeling that our country is too little known to other countries, have prompted a descriptive tone-both as to scenery and manners-an appearance of the attempt to give information-which has almost put them out of the pale of fiction and within that of travels." The New York Review, in a largely favorable review of Kennedy's Horse-Shoe Robinson, observed that "the descriptions of scenery are eminently graphic, but they are too much in detail, and perhaps there are too many of them" (January I 842). Knickerbocker likewise objected, in June I 849, that 
in My Uncle the Curate "the scenic features of the landscape, and of the transitions of day and night, are a little over-described" (June I 849). And the Home Journal found a fault in "the too great exuberance of fancy in the descriptions of external nature" in Ann Stephens's The Old Homestead (October 27, I 855).

In February i8 52 Godey's carried an essay by one of its contributing editors, Alice B. Neal, containing advice to would-be authors. She wrote that "the descriptions of natural scenery [should be] few and delicately handled-we say few, because readers generally are not interested in a geographical description of mountains and valleys that never existed, and that do not increase the excitement of the plot, or hasten the development of character. It is a form of amplification that too often serves only as a cloak for poverty of material." This general view was echoed by the Atlantic, whose reviewer complained about Anna Mowatt Ritchie's Twin Roses that "the defect, which especially mars the latter portion of the volume, is the absence of any artistic reason for the numerous descriptions of scenery which are introduced. The tourist and the novelist do not happily combine" (May I 858). An Atlantic reviewer also faulted The New Priest in Conception Bay because "descriptions of scenery are too frequently introduced, and pushed to a wearisome enumeration of particulars and minute delineation of details. . . . Scenery-painting in words is a characteristic of most recent American novels. . . . Every rock, every clump of trees, every strip of sea-shore, every sloping hillside, sits for its portrait. . . . When human hearts and human passions are animating or darkening the scene, we do not want to be detained by a botanist's description of plants, or a geologist's sketch of rocks" (December i 858).

But judicious scenic description merited praise. A Knickerbocker review praised Maria McIntosh's Two Lives because "her descriptions of scenery and the phenomena of the elements are clear and not over-labored" (October I 846); Peterson's liked the "descriptive passages, scattered everywhere through the pages, which bring before us the scent of clover, the hum of bees" in Warner's Say and Seal (June I 860). Godey's praised one novel for "many a beautiful picture of natural scenery," another for "pictures of western scenery," and another still for "beautiful scenery" (November I 850, August I 854, December I 856). The Tribune wrote of A. S. Roe that "few writers excel him in the delineation of American 
rural scenery" (October I 2, I 858). Thus reviewers thought that descriptions of natural scenery, if not too lengthy or too detailed, might make pleasurable reading, but usually thought them an excrescence more likely to annoy than interest. They took a more relaxed line toward local color. While there was no formal need for rich detailing of setting except in the special case of the historical novel, a novelist might, they agreed, establish a strong secondary interest by presenting the manners and customs of a given place. American novelists, self-conscious about the uniqueness and transience of many aspects of their national life, might particularly aim for such a subsidiary interest. To some degree the presence of such an interest constituted a fictional subgenre.

Godey's, which had a strong literary nationalist bias, was especially concerned to point out and praise local color novels. The reader of Talbot and Vernon "will find much to interest him in the descriptions of western life and manners," Lonz Powers was admirable for its "various descriptions of primitive society in the West," Tempest and Sunshine "makes us acquainted with many interesting features of western life," the novelist Emerson Bennett's "pictures of western scenery, and delineations of western character, and of early life in the backwoods, have rarely been surpassed," Farmingdale was a "quiet New England story, in which the domestic manners and the peculiarities of the people are ably and interestingly portrayed," and Ironthorpe, the Pioneer Preacher "will no doubt prove most acceptable to that numerous class of readers who desire to be made acquainted with the peculiarities and adventures of western pioneer life in the early settlement of that region of our country" (July i 850, October I 850, December I 850 , July I 854 , August I 854 , July I 855 ).

Other journals also pointed to local color in novels, again especially American novels. Grabam's praised Redwood: "the best account we know of life among the Shakers"; Farmingdale: few books "represent with so much freshness and closeness the ordinary life of New England"; Eastford: "a representation of common aspects of New England life and character"; Richard Hurdis: "scenes and characters peculiar to the roughest border life"; The Torchlight: "American home life as it really is in the country"; The Border Rover: dealing with "that spirited and dramatic yet eminently natural life of the West, which, as every one knows, is extremely interesting to the reading class at large" (August I 850, 
October I 854, April I 855, November I 855, January I 857, June I 857). Putnam's reviewers did not rate $A$ Long Look Abead high "as a work of art," but they found value "in its detailed, truthful delineations of New England life," and they described Wolfsden as "a tale of New England domestic life, faithful to local scenery and manners in many respects, and not without merit as a fable" (May i 855, March i 856).

The reportorial interest in local color novels was often viewed as a distraction from rather than an enhancer of the primary interest of plot. Local color therefore called for labeling so that the reader would know that the intense ongoing interest of the "novel proper" was likely to be diluted by accounts of regional life. For those mainly interested in the reportorial material the fable might seem intrusive. Something of the same problem obtained in travel literature; indeed, it is not unfruitful to think of local color writing as an intermediate form between travel literature and fiction. For those interested in actualities the fable might be more than distraction; it could falsify. Therefore the form of choice for local color or regional writing during these years was the sketch, a mode with loose structural requirements. Certainly the bulk of the volumes of sketches reviewed in these years were American collections with a strong local color emphasis: in these instances the question of the "fable" did not have to arise.

Whenever the local color writer attempted to claim either the popularity or prestige of the novel form by composing local color novels, the reviewers responded by a mode of analysis that in effect undercut these claims, suggesting that readers should approach the works for the intermittent rather than the continuing, shapely interest of the novel. In so doing, they made it clear that the local color novel was an artistically and emotionally weaker variant of the novel proper. "A pleasant and graceful little humorous tale of New England life." "Not without merit as a fable." These problems with respect to the handling of local color in long fiction are precisely those that we meet again later in the century when local color and regional writing became, according to standard literary history, a dominant mode in American fiction. In fact it appears that the form was a product of the earlier period, and just as dominant then, already recognized by reviewers as a characteristic American imaginative response to its own experience. Why has it been held to emerge in America only 
after the Civil War? First, because it has been perceived as a nostalgic reaction to the disruptions of the post-Civil War years and hence requiring those disruptions as a precondition; second, because deferring it to the end of the century has permitted present-day critics to offer the "romances" of Hawthorne and Melville, and hence the "romance" itself, as the practice of the American artist in midcentury. Of course, as reviewers of their own day make clear, Hawthorne and Melville were not representative American artists of their time.

In what we may think of as a formal struggle between plot and reportage within the local color novel, plot was bound to win if the novel was to remain a novel. If we look closely at the descriptions of local color novels in the reviews above, we observe that the critics were separating out two forms of the mode, the New England novel and the western. Each of these forms carried its own inherent expectations with respect to action and character. New England stories were invariably "quiet"; their settings were rural, their scope domestic. It is clear from the reviews that western stories were extremely popular, and it is difficult not to suppose that the basis of that popularity was the action rather than their fidelity to details of western life. One reviewer, in fact, says as much. This is the Literary World for October 5, I 850, reviewing James Weir's Lonz Powers:

It is seldom that we meet with a book upon which it is so difficult for us to express our opinion, as this. The characters and incidents-wild and improbable as they may seem to the northern reader-are true to the life, while the language of the actors is generally unnatural, and entirely out of keeping with the location of the scenes.... The different phases of southwestern life, as exhibited in the last twenty years, present a rich, and, as yet, untenanted field for the novelist. That this has not been properly improved is, perhaps, owing, in a great measure, to the innumerable trashy, horrible, and utterly false "raw head and bloody bones" stories of that region, with which we have been inundated usque ad nauseam. There exists no necessity for the romancer's drawing upon his imagination to produce bloody-minded but chivalrous robber heroes, or accomplished and amazingly beautiful heroines. . . . Quite enough of the heroic and romantic may be found, readymade to the author's hand, without his indulging in such ridiculously stupid and outrageously improbable fictions, as many 
have done, who, knowing nothing of the ground, sit quietly in their chimney corners and deluge a credulous world with a careless stream of senseless trash.

This review permits us to question the usefulness of the local color novel as a vehicle for information and to propose that, whatever the writers had in mind, readers resorted to them, as to other novels, for story. The fable underlying western fiction had little or nothing to do with the actualities of western life; it was rather an imaginative construct proposing an alternative life, featuring the "West" as a remote place. Its value was precisely that assertions about life there could not be tested by the average reader, and thus the newfangled novel's obsession with probability could be circumvented.

If one of the two types of local color novel was unreliable, and really plot- rather than information-based, what of the other? The New England novel claimed fidelity to actualities by the quietness (that is, the dullness) of its material, boredom being an apparent earnest of accuracy where New England was concerned. To some extent we may suppose that the New England novel indeed was more accurate; I want to qualify this not unreasonable conclusion, however, in two ways. First, it may be that the very "quietness" of the type represented a fabulous expectation: if the western novel corresponded to the old adventure story, the New England novel was a modern pastoral. Second, we know that, among these New England novels, those that attained the greatest popularity (especially after i 850 ) focused on young heroines and contained a repeated plot that I have written about in another book; they were "woman's fictions" telling stories about the trials and triumphs of young women and hence structured as mythos.

If we return to a review of books by the Warner sisters (North American, January I 853) that I have quoted for other purposes in chapter 3 , we may sense that, although these works were commendable for regional accuracy, this was not the reason why little girls, elder sisters, mamas, papas, and sober bachelors were all under the spell of The Wide, Wide World and Queechy. "As a matter of pure judgment," the review observes, "we must place their pictures of American country life and character above all their other merits, since we know not where, in any language, we 
shall find their graphic truth excelled." But, it goes on to ask, "what are the grounds of the admiration, or rather love, excited by these books?" (clearly implying that pictures of American country life cannot be the answer). "The interest . . . lies in a most life-like picture of the character and fate of a little girl . . . such as any of our daughters may be; unfortunate in some respects, happy in others; dependent, as all little girls, whatever their station or fortune, must be, on the virtue and affection of those about them; but showing, what all little girls cannot show, a degree of character, a firmness of principle, a sweetness of disposition, by no means impossible under the circumstances, yet far enough raised above common experience and expectation, to excite the imagination and stimulate the sympathy. . . . We care for all else only as this little piece of tender, budding womanhood is affected or influenced." Since this perceptive reviewer was addressing the adults who read the North American, she or he is not wrong to characterize Ellen as resembling "our daughters." The point, however, gains in significance when we remember for how many readers of The Wide, Wide World Ellen was like themselves.

\section{Dialogue}

The reviewers' common term for dialogue was "conversation." Unlike narration or description, it was not thought of as a necessary formal aspect of the novel, yet no reviewer expected to find a novel without it. Conversation served two literary functions. As an alternative to the narration, which was expected to be delivered in a single, conventional voice from a conventional stance, conversation introduced a certain amount of lexical and syntactic relief. In addition, conversation provided an opportunity for introducing wit and repartee enjoyable in themselves. Conversation thus was thought of in relation to or in distinction from narration and description. Addressing aspiring authors, Godey's counseled that "the conversations should be spirited or thoughtful . . . but always remember that they are conversations, and in real life one rarely moralizes a whole page without even a comment or ejaculation from the listener. Nor does a colloquial style often admit of sentences Johnsonian in length and finish. It is, more properly, characterized by abrupt transitions, terse opin- 
ions, or brilliant sallies" (February I $85^{2}$ ). We can see here that a certain norm for spoken as opposed to written language, rather than notation of individualized speech, represents the desired achievement of conversations in novels. In fact, the use of dialogue for character development was not invariably perceived as good artistic practice, as this comment from the New York Review for January I 842 indicates: "The necessity of making the individuals introduced tell much of the story, and exhibit their motives and peculiarities in speech, has involved the author at times in discussions that are unnecessarily long, and delay rather than advance the plot."

The great danger that reviewers saw in conversation was tedium; dialogue might be stuffily formal or simply go on too long. "The conversations are not so protracted to become tedious," a Mirror reviewer wrote approvingly of Cooper's Homeward Bound on August i 8, i 838, setting out the criterion for all to see. Looking back on Cooper in April I 850, the American Review commented that "the general level of the dialogue among the principal characters in Cooper is what, in our school days, was denominated the 'high-flown' school. . . . The first principle in elaborating a dramatic construction, of whatever description, whether re-related in narrative or represented in a dialogue, or both, is action."

Complaints of overextended or stiff dialogue run through the reviews, suggesting that novelists faced a real challenge in trying to handle this aspect of their craft. "She made her ladies and gentlemen talk a vast deal too much, and too much like books" (Knickerbocker, October I 855); "the dialogue is often heavy; the speakers make long orations . . . not only longer than any real talker ever made, but in a style such as no good talker ever used" (Tribune, March I 2, I 845); "the conversations are spun out to a tedious length" (Tribune, December 27, I850); "the book is eked out by long and often tedious dialogue" (Literary World, July 6, I850); "we would in a friendly spirit warn the fair author to guard against prolixity in her dialogue" (Literary World, June I 2 , I 852 ); "the personages of the tale fail to interest because they one and all 'talk like a book.' Ease and nature are wanting" (Literary World, December I 8, I 852); "the conversations are singularly stiff and artificial, sometimes regular forensics" (Christian Examiner, May I 85I); "her only danger, as far as the story is con- 
cerned, is allowing her conversations to occupy too much space" (Godey's, July I 854); "we must remonstrate with the author, too, for impeding the story with those interminable discussions" (Southern Literary Messenger, October I 855); "the style is a little too much diluted with dialogue" (Christian Examiner, January I 858); "the conversations are too numerous, too protracted, and run too much into trivialities and details" (Atlantic, December I 858); "the plot, such as it is, moves onward through a wilderness of talk, inferior in force, freshness, and dignity to the ordinary conversation extemporized in drawing-rooms" (Knickerbocker, October I 859).

The reference to the drawing room makes explicit the implicit assumption that the conversational norm invoked in these judgments is linked with the idea of manners. While stiff formality in conversation is deplored, conversation itself is a sort of ritual conducted according to rules. Perhaps this norm is associated with a now-vanished notion of conversation as a social activity, an association that would explain why conversations were not seen as automatically connected to plot and character but rather were linked to general ideas of wit and vivacity. "The dialogue of this story strikes us as the best part of the book; it has all the vivacity and the air dégagé, of the polished circles in which [the author] may be supposed to move" (Godey's, November I 840); "contains many sprightly and laughter-moving conversations," "several of the conversations are exceedingly amusing," "the various conversations with which the volume is replete are of the most readable and pleasant nature" (Democratic Review, September I 846, October I 846, December I 846). The conversations are "sparkling with wine and confectionery" (Mirror, April I5, I 850); "the genial vivacity and sparkling wit of her conversational pages have rarely, if ever, been equaled" (Democratic Review, March I 855).

Although we might conclude from these examples that only well-bred characters were supposed to speak in novels, from time to time in this criticism we read that the dialogue attributed to a given character is or is not appropriate to the character itself. The North American, for example, objected in January i 846 to Judd's Margaret because it made the heroine "speak in a dialect which resembles nothing ever heard in the social world, and which is wholly out of nature in a village girl, whatever the accidental 
circumstances of her education may have been. It destroys the beauty and truth of the conception." It may be a sign of changing times that the criterion of individuality in dialogue appeared more frequently in novel reviews of the i 850 os than earlier. "The actors for the most part, are made to reveal themselves in the brief, pithy, pregnant dialogue" (Tribune, July I 2, I 854); "characters, young and old, male and female, polished and unpolished, talking with a rare naturalness, and developing their peculiarities in this way, instead of having them described narratively by the author" (Peterson's, September I 854); "the dialogues are generally brief, pointed, and appropriate to the interlocutors" (North American, October I 855). Complaints about excessive use of characters speaking in the vernacular, common before 1840 , also dropped off in the 1850 .

\section{Reflections}

Reflections or sentiments, shading off into a moral, were also usual and acceptable ways to vary the narrative surface. The moral (discussed at more length below) was technically a detachable summary statement, usually found at the end of a novel, on which it provided a sort of gloss. Morals were much more common in short tales and stories than in novels, since the complexity of a novel's plot tended to resist easy summation. Reflections or sentiments, by contrast, arose more locally from an incident or occasion in a novel, representing a brief detour from the progress of the action that might have an independent attraction for a certain kind of reader, especially one who kept copybooks. St. Leger, according to the Literary World for January 5, i 850, contains "many little expressions which are so agreeable to those who keep common-place books, concentrated thoughts, which are not too long to be copied." Reviews, especially in the earlier part of the period under study, tended to feature long abstracts from novels they were writing about, often appropriately titled (e.g., "on beauty") for copying convenience. "The following thoughts are beautiful and truthful," the Literary World wrote before beginning its extracts from The Head of the Family (March 27, 1852). For some reviewers the presence of reflections indicated the writer's attempt to produce a serious novel that aimed 
for more than story, and they approved the convention-providing, of course, the reflection was sufficiently lofty.

The Mirror disliked Mary Howitt's Little Coin, Much Care but noted that the "incidental reflections are excellent in their tendency" (August 6, I 842). Godey's reviewers applauded The Moneyed Man by Horace Smith for "judicious reflections that are scattered throughout it, and the praise-worthy moral it enforces" (August I 84I); found the "reflections" in Bulwer's Zanoni "original, profound, and just" (June, I 842); praised the author of The Lamplighter for "the just, generous, and charitable sentiments that profusely flow from her pen" (July I 854); and wrote of The Old Farm House in September I 855 that "many of the reflections are very fine, and alike honorable to the head and heart of the author." Grabam's reviewers found the "sentiments" in Grace Aguilar's Vale of Cedars "beautiful and pure" and saw "the original and striking observations on life and manners" as constituting "no small portion of the charm" of Thackeray's works (November I 850 , January i 853). A Harper's review commented on The Old Plantation by James Hungerford: "the narrative is occasionally diversified by a vein of reflection, showing the aptitude of the writer for the more serious exertions of the intellect" (March I 859). In Ida Norman "the sentiments are just, beautiful, noble, and exalted" (Home Journal, March 24, I855).

But even reviewers who liked reflections admitted that too many destroyed the novel's interest, however admirable in themselves the sentiments might be. And overall, a preponderance of novel reviews disapproved of the convention of the reflection. As early as April I 829, the North American compared Bulwer unfavorably to novelists who "do not frequently interrupt the narrative, and suspend the action, with comments and dissertation." It also criticized G. P. R. James for placing "a moral reflection, or a feeble speculation, at due pauses in the march of his story, with a sort of mathematical precision. ... This is "from the purpose' of novel-writing" (April I 844). "Excessively annoying," the Southern Literary Messenger wrote about James, "is his habit of obtruding passages of reflective writing in the way of his story" (September I 847). Standish the Puritan, Harper's said, "would have had still greater effect if not so freely blended with moral disquisitions" (June I 850). The Tribune for May 15, I850, shared this view: "he indulges too freely in abstract reflection"; it also 
criticized The Wide, Wide World for "moral and religious reflections" that "are lugged in without regard to propriety or grace," saw Hearts Unveiled as "clogged by long didactic disquisitions," and described My Brother's Keeper as falling "into a train of pious moralizing in which gentle dulness is too prominent an element" (December 27, I850; April 30, I 852; May 16, I855). Harper's, again, observed that in Clifton by Arthur Townley "the plot has no special interest, and is in fact subservient to the taste for dissertation" and that Martha Wickham's Sea Spray is "encumbered by a superfluity of moral reflections" (July 1852, April I857). While reviewers wanted novels to be more serious than they usually were, over time they also became increasingly critical of reflections and sentiments employed as a means to this end.

\section{The Moral}

The moral posed more serious problems than did the reflection to proponents of the better novel, since the latter was at worst an interruption while the former gestured toward a nonfictional organizing principle. Morals, too, were differently situated with respect to readers-reflections were to be admired and perhaps copied into commonplace books, while morals were to be acted upon. "The moral lesson inculcated" in a certain novel is "important and instructive," according to the New York Review for July I 840. "Her moral is always good"; "the moral is excellent"; "the lessons it contains are all excellent"; "the moral it conveys is an excellent one"; "the moral is pure and healthy"; "it has pure and blessed teachings for all lives" (Godey's, November I849, July I 854, February I 855, March I 855, January I 856). "Can be recommended for its just sentiments, Christian teachings, and pure moral," "the principles inculcated are of the highest practical importance," "inculcating a good moral" (Home Journal, January 14, I 854; March 24, I855; May 31, 1856). Putnam's called a novel's moral "pathetic and impressive" (November I 856); Grabam's praised Southworth's novels because "the whole invariably tends to a pleasing moral" (April 1858).

We cannot comprehend these critical comments without understanding that they distinguish between a novel with a moral, 
the moral tendency of the novel, and the didactic novel. The didatic novel is an identifiable subgenre (see chapter Io). The moral "tendency" of a novel is an inevitable, invariable aspect of any novel whatever, resulting from the way sympathy is disposed among morally good and bad characters as well as the way morally sensitive material is handled (see chapter 9). A "moral" is rather more limited than either of these, though more related to the didactic novel than to the concept of moral tendency.

Those who inserted morals into novels were apt, from an artistic point of view, to err in two ways: to fail to assimilate the moral smoothly into the narrative flow, and to assume a strikingly inappropriate narrative tone for a novel when articulating it. As early as July I 827 the North American had asserted that a moral "sturdily inculcated or illustrated in every page . . . or which in any degree diverts the current of events from their natural course, occasions a violence to probability, revolting both to the taste and conviction of the reader." "There is one noticeable defect, in the management of the moral," Putnam's wrote about Heartsease. "This, which was apparently intended to permeate the whole texture, is stuck in in unassimilated, uncomfortable lumps. We come upon them as upon an unexpected jolt" (February I 855). "The moral is an excellent one," the Democratic Review wrote of Roe's A Long Look Abead, "and not impaired by being made too manifest, too predominating, and obvious throughout; it is suggested and enforced by the story in a true artistic spirit, but does not stick out through the fiction, like a rusty nail through a butterfly" (April I 855).

Lumps of moral were bad, but a pedagogical tone was worse still. In July i 847 the North American pointed out that "we read novels, first of all, to be amused; and we feel rebellious at an over-dose of the didactic smuggled into them against our will. It also seems to us, that an author is taking advantage of his position, when he moralizes too severely." Talbot and Vernon, according to the Tribune, was free "from that dry and didactic tone which usually ruins an attempt to inculcate a specific moral in a work of fiction" (May 1 5, I 850). "The moral which is the design of the story is brought forward too prominently" in Oakfield, it noted on October 30, I 855 , "and at times almost chills the interest of the narrative by its cold, didactic formality." "No man bidden to a feast of fiction expects to sit down to a sermon," 
Putnam's announced in May I 853. "There is a general tendency in the composition of the work to a didactic and somewhat pedagogical method," the Ladies' Repository wrote of The Methodist in May i 859. Severity, coldness, dryness-these aspects of the didactic tone are inappropriate to the narration of a novel. Novel readers do not want to be returned to the schoolroom or the church and will not accept the novelist as teacher or minister.

The more artistic way to present a moral, then, was to avoid a didactic, pedagogical tone and if possible conceal it in the fabric of the story. According to the Democratic Review, the moral of Grace Lee by Julia Kavanagh was "more powerful, because it glides into the intellect intuitively, and [is] not thrust on us with any Pharisaic ostentation" (May I 855). The Literary World reviewers liked a novel whose high moral aim was "implied rather than forced on the reader's mind," and they approved of Caroline Lee Hentz because the lessons she "inculcates are not delivered in a dictatorial, self-sufficient manner, but ingeniously woven in with the story, imparting to it force and reality, without diminishing its romance or interest" (October 9, I 847; April 3, 1852). Two matters are at issue here: first, the primacy of the story; second, the way the writer talks to (or writes to) the reader. The novelist who assumes the manner of a pedagogue has made the political mistake of situating himself or herself above the reader. In the novel-reading situation power is invested in the reader who has bought the book and having done so may or may not read it, may or may not finish it, and may or may not buy another book by the same writer. An author who assumes superiority either is ignorant of, or is attempting to override, this essential aspect of writer-reader relations.

The writer, then, who wants to push the novel form toward pedagogy can succeed with novel readers only through more subtle and more manipulative methods than openly ascending the platform. The method recommended by reviewers was to get readers to find the moral themselves. Such a procedure would give readers the illusion of control; and what is more, it would mime the shape of a plot where discovering secrets is at the heart of the reading process. Without inculcating "any special moral axiom," the Atlantic wrote about Vernon Grove, "it embodies . . . many worthy lessons for the mind and heart. This is done, as it should be, by the apparently natural development of 
the story itself. For, as we have said, the book is really a novel, and will be read as a novel should be, for the story" (January I 859). In the phrase "apparently natural" the review acknowledges the presence of a deception it deems allowable, even necessary when a novelist wants to convey a lesson.

"When we speak of a distinct moral aim as indispensable to the novelist, we do not mean that he should be constantly thrusting his moral into the reader's face, - - one of the weakest pieces of folly an author can commit. . . . But there must be that spiritual vitality, that life of the affections, that devotion to human weal, which, revealing themselves insensibly, quicken the reader's resolutions, and leave him with a clear consciousness that his soul has been enlarged" (Christian Examiner, January I 847). The novel "inculcates without intruding," the North American said approvingly of Mary Jane Holmes's The English Orphans in October I 855; and of other novels: "fraught with the highest truths of morality and religion; and these are not obtruded upon the reader, but so incorporated with the whole texture of the tale, that he must either take them in, or leave the book unread"; "lessons of faith and piety are embodied in the life-experiences of the characters, not set forth in formal dialogues or in the author's running commentary"; "this unambitious plot is naturally developed in such a way as to be eminently suggestive of prudent counsel, high motive, and strenuous endeavor, while the author never assumes the didactic form, but moralizes only by the skillful collocation of actions and their consequences, incidents and their issues" (January I 858, October I 858).

Lest we too quickly associate the desire for hidden morals in fiction with a dated gentility, consider what happens to this criticism when the word "theme" is substituted for the word "moral." Then, what these reviewers are recommending is precisely what academics consider praiseworthy in novels today; finding themes is the end and method of teaching in literature classes across the nation. Most college teachers today assume that a student who talks about plot and characters rather than offering an interpretation that involves theme is "naive." For more advanced literary theory we should substitute the word "meaning" for the word "moral" to situate ourselves in the wake of history. In this talk about the hidden moral in fiction we see the origins of modern theme study and modern meaning study, the search for 
I 28 Novels, Readers, and Reviewers

the significance that, being "well wrought into the texture of the work, but never officiously presented" (North American, April I 825), justifies the reading act for those who, wishing for various reasons to attach themselves to the novel, cannot accept the pleasure of story as one of these reasons. 